\title{
ADH4 Gene
}

National Cancer Institute

\section{Source}

National Cancer Institute. ADH4 Gene. NCI Thesaurus. Code C111829.

This gene plays a role in the oxidation of alcohols. 